\title{
THE MINISTER OF JUSTICE OF CANADA v. JOSEPH BOROWSKI \& ATTORNEY GENERAL OF ONTARIO ET AL.*
}

\author{
KAREN SWARTZENBERGER**
}

\section{A. INTRODUCTION}

The Borowski decision is the third major judgment of the Supreme Court of Canada in the past decade on the issue of standing to challenge the constitutionality of legislation. The case arose when a Canadian citizen attempted to challenge the constitutional validity of the Canadian abortion laws, ${ }^{1}$ alleging that the present law infringes the right to life as declared in s. 1 of the Canadian Bill of Rights. ${ }^{2}$ On a superficial level, the decision appears to follow the two earlier decisions: Thorson v. Attorney General of Canada and The Nova Scotia Board of Censors and Attorney General of Nova Scotia v. McNeil. ${ }^{4}$ In both of these cases, the majority decisions granting standing were written by Laskin C.J.. Therefore it is noteworthy that the Chief Justice dissented from the majority opinion in the Borowski case which also found the plaintiff to have standing. This has led to a certain amount of criticism by constitutional lawyers who find the minority decision result-oriented and inconsistent with the past trend towards broadening the grounds of standing. It is the thesis of this paper that, on the contrary, the dissenting opinion is entirely consistent with the earlier judgments.

The Borowski case raises basic policy questions as to the purpose served by our locus standi requirements, the function of the judicial system in today's society, as well as the role of the public in the judicial system. Should the rules of locus standi operate so as to conserve our limited judicial resources? Do we wish to encourage public participation in enforcing the constitutional limitations on legislation or should we discourage such meddling by "busybodies"? And finally, is the Supreme Court of Canada or Parliament the more appropriate body to decide the fate of those Canadian women who decide to have abortions?

All legal systems face the same conflict between "the desirability of encouraging individual citizens to participate actively in the enforcement of the law, and the undesirability of encouraging the professional litigant and the meddlesome interloper to invoke the jurisdiction of the courts in matters that do not concern him." 5 Therefore most systems include the concept of standing and require an individual to have some special personal interest in the subject matter of the dispute beyond that of the general public before being allowed to litigate. ${ }^{6}$

* [1982]1 W.W.R.97 (S.C.C.); affg. [1981]1 W.W.R. 1 (Sask. C.A.);revg. [1980]5 W.W.R.283 (Sask. Q.B.).

** Of the graduating class of 1982, Faculty of Law, University of Alberta.

1. Criminal Code, R.S.C. 1970, c. C-34, s. 251, as am.

2. Canadian Bill of Rights, S.C. 1960, c. 44, as am..

3. [1975] 1 S.C.R. 138; revg. [1972] 1 O.R. 86 (Ont. H.C.).

4. [1976] 2 S.C.R. 265; revg. (1974) 9 N.S.R. (2d) 483.

5. Leslie A. Stein, Locus Standi (1979) 3.

6. Id. at 6; De Smith's Judicial Review of Administrative Action (4th ed. J.M. Evans ed. 1980) 410 . 
The purpose of this paper is to examine the function and recent history of locus standi in Canada by reviewing the important decisions in this area and then discussing the ratio of the Borowski decision in light of such case law.

\section{B. DEFINITION AND FUNCTION OF "LOCUS STANDI"}

A passage from Leslie Stein's work, Locus $S t a n d i{ }^{7}$ gives a general definition of the term and a description of the function of such a requirement in the judicial system:

The terms "locus standi", "standing to sue", and "title to sue" denote the existence of a right of an individual or a group of individuals (not necessarily constituting a legal entity) to have a court enter upon an adjudication of an issue brought before that court by proceedings instigated by the in dividual or group. That right, once found, exists apart from the factual or legal merits of the issue before the court or the jurisdiction of the court to adjudicate upon the issue.

Frequently, however, the question of standing is confused with other related, although theoretically distinct, considerations such as whether it is a hypothetical or moot question being presented to the court; whether it is a political question; whether it is a justiciable question; or whether the remedy sought is appropriate. This may lead to problems in determining the ratio of a decision.

A decision by a court that a plaintiff lacks standing may have farreaching consequences because it "precedes any joining of issue on the merits of the case and any taking of evidence and operates ... to prevent the merits ever being aired in a court." ${ }^{\prime 8}$ Unless another plaintiff comes forward who meets the requirements of standing, the result may be to preclude consideration of an extremely important matter and thus, otherwise illegal action may continue without redress. ${ }^{9}$

A court in deciding a question of standing must set "the appropriate threshold level of interest" in general and must measure the plaintiff's stake in the instant matter. Where the plaintiff can demonstrate an economic injury, the problem is much simplified. But where the plaintiff is complaining of injury to other values, whether political, ecological, or religious, as is arguably the case in the Borowski decision, then the task of measurement is much more complicated. ${ }^{10}$

\section{STANDING PRIOR TO THE THORSON DECISION}

The leading authority prior to the Thorson decision in 1975 was John T. $S m i t h$ v. Attorney General of Ontario. ${ }^{11}$ In this case, the plaintiff, a resident of Ontario, ordered a quantity of liquor from a firm in Quebec. The firm refused to fill the order because to do so would be a violation of the Ontario Temperance Act which prohibited the importation of liquor into the province. Smith therefore sought a declaration that the Act was not in force within the province. The Supreme Court of Canada was unanimous in finding that the plaintiff lacked standing. Two reasons were cited for this finding. The first was that the case was based on a mere hypothetical state of facts in that Smith was acting under no actual threat or risk.

7. Supra n. 5 at 3.

8. John M. Johnson, "Locus Standi in Constitutional Cases After Thorson" (1975) Public Law 137 at 139.

9. Supra n. 5 at 4.

10. Kenneth E. Scott, "Standing in the Supreme Court - A Functional Analysis" (Feb. 1973) 86 Harv. L. Rèv. 645 at 674 .

11. [1924] S.C.R. 331; affg. 53 O.L.R. 572 (S.C.A.D.). 
Although the Court had some sympathy for Smith's argument that he should not be forced to subject himself to criminal proceedings in order to challenge the legality of the statute, any such sympathy was more than outweighed by their second reason for denying standing. This reason was the Court's concern over the grave inconvenience that would result if each and every citizen were recognized as having the right to "initiate proceedings impeaching the constitutional validity of any legislation directly affecting him, along with other citizens, in a similar way in his business or in his personal life."12

The above case was consistently followed in Canada and was interpreted in Cowan v. C.B.C. as establishing the following rules with respect to standing: ${ }^{13}$

A plaintiff can sue without joining the Attorney General in two cases: first, where the interference with the public right is such that some private right of his is at the same time interfered with ....; and, secondly, where no private right is interfered with, but the plaintiff, in respect of his public right suffers special damage peculiar to himself from the interference with the public right.

These requirements have been described as a "seemingly inpenetrable barrier to private citizens launching challenges to the constitutional validity of legislation." 14 But such was the law applied by Canadian courts until the Thorson decision in 1975.

\section{THE THORSON DECISION}

This decision was the first significant change in the case law with respect to standing required to challenge the validity of legislation. The plaintiff here brought an action as a taxpayer and on behalf of all other taxpayers of Canada for a declaration that Parliament had no jurisdiction to enact the Official Languages Act or the corresponding Appropriation Act. The Ontario High Court followed the earlier Smith reasoning and denied the plaintiff standing. It stated that a plaintiff must be "specially affected" or "exceptionally prejudiced" in order to have standing to challenge the constitutional validity of an Act of Parliament.

However, an appeal to the Supreme Court of Canada was successful. Chief Justice Laskin wrote the majority opinion in the 6 to 3 decision and Martland, Ritchie, Spence, Pigeon and Dickson JJ. concurred with him. Chief Justice Laskin began by discounting the earlier concern over the grave inconvenience and public disorder which had been anticipated as the probable result if virtually every citizen had the right to challenge any legislation. In his opinion, the courts themselves could control the "floodgates" by the use of their inherent discretion, by directing a stay or by imposing costs. He stated that the question of the legislature exceeding its powers is a "matter traditionally within the scope of the judicial process. ..."15

Chief Justice Laskin also discounted the "exceptionally prejudiced" test from Chief Justice Duff's judgment in the Smith case. This test was developed in earlier English cases of public nuisance and he found it inappropriate where the constitutional validity of legislation was the issue sought to be raised. Whereas an Attorney General could be expected to

12. Id at 337 .

13. [1966] 2 O.R. 309 at 312, 56 D.L.R. (2d) 578 at 581 (C.A.).

14. David Mullan, "Standing After McNeil" (1976) 8 Ott. L. Rev. 33 at 34.

15. Supra n. 3 at 145.

16. Id at 147-148. 
be sensitive to and to act upon complaints of an interference with public rights by a third party, it was much less likely that, given his position in today's government, an Attorney General would be willing to challenge his own legislation.

The ratio of the Thorson case emphasizes that there was no other practical method to challenge the impugned legislation which Laskin C.J. classified as "declaratory and directory". This was in contradistinction to "regulatory" legislation, which ${ }^{16}$

... being legislation which puts certain persons, or certain activities theretofore free of restraint, under a compulsory scheme to which such persons must adhere on pain of a penalty or a prohibitory order or nullification of a transaction in breach of the scheme, they [the persons regulated] may properly claim to be aggrieved or to have a tenable ground upon which to challenge the validity of the legislation. In such a situation, a mere taxpayer or other member of the public not directly affected by the legislation would have no standing to impugn it.

But where legislation is declaratory, all citizens are generally affected in a similar way and therefore no one of them could claim to have standing under the former rules. This, Laskin C.J. found to be unacceptable: "I am unable to appreciate how an argument of principle can be made that such a wrong, an illegality that is certainly justiciable, should go uncorrected at law, whatever may eventuate as political redress." ${ }^{17}$ Although Laskin C.J. in a later case qualified this distinction between regulatory and declaratory legislation, the distinction continues as an important factor and it is submitted to be of great importance in the Borowski case.

The judgment also emphasizes that a finding of standing is at the court's discretion. This is especially true where a taxpayer seeks to challenge the constitutional validity of legislation. Two factors are pointed out as central to the exercise of that discretion. One was the "justiciability" of the issue sought to be raised. The second was whether the legislation was regulatory or declaratory.

The judgment concludes with a sweeping statement: "It is not the alleged waste of public funds alone that will support standing but rather the right of the citizenry to constitutional behavior by Parliament where the issue in such behavior is justiciable as a legal question."18

A summary of this decision's effect on the question of locus standi is as follows: ${ }^{19}$

The general rule of locus standi remains: only the Attorney General acting ex officio or ex relatione has the necessary standing to sue in regard to an alleged public wrong. The exceptions to this general rule are as follows:

1. Statutory powers in Canada allow the Governor in Council and the Lieutenant Governor in Council to "refer" certain matters directly to the courts for advisory opinions.

2. An individual plaintiff has standing to sue without joining the Attorney General if:

a) the interference with a public right is at the same time an interference with a private right of his, or

b) the plaintiff "suffers special damage peculiar to himself from the interference with the public right"

This is the rule stated by Buckley J. in Boyce v. Paddington Borough CounciL

3. Pursuant to Thorson v. A ttorney-General of Canada, an individual plaintiff has adequate standing to sue without the participation of the Attorney General if:

i) it is "a justiciable issue respecting the validity of legislation" ...

ii) the appropriate Attorney General ... has refused his consent to relator proceedings ... .

iii) the Governor in Council or Lieutenant Governor in Council, whichever is appropriate, has been asked to make a reference and has declined to do so. There is no authority in the judgment of Laskin J. for this requirement .... .

17. Id. at 158 .

18. Id. at 163 .

19. Supra n. 8 at 158-159. 
iv) the legislation does not impose prohibitions or restrictions on a particular class of persons "who would thus be particularly affected by its terms beyond any effect upon the public at large" but rather affects all members of the public or a wide segment thereof alike, or the legislation does impose prohibitions or restrictions on a particular class of persons, and the plaintiff:

a) is within such class, and

b) is not just remotely or theoretically affected; $i e$. he is significantly involved even if he has stopped short of actually subjecting himself to penalties.

v) the court in its discretion accords standing to the plaintiff in question.... Presumably, however, satisfaction of the above criteria would in a sense "shift the onus" such that a court should accord the plaintiff standing unless there is a cogent reason for not doing so.

Obviously, the grounds of standing were drastically increased by this decision and the change was generally welcomed. The requirements for standing were varied again but only slightly in the McNeil decison which followed within a year.

\section{E. THE McNEIL DECISION}

The $M c N e i l$ decision is generally regarded as having further broadened the grounds for standing and to have lessened the importance of any distinction in terms of standing as between regulatory and declaratory legislation.

In $M c N e i l$, the plaintiff applied as a resident and taxpayer for a declaration that the Theatres and Amusements Act of Nova Scotia and the regulations thereunder were ultra vires the provincial Legislative Assembly. Because the effect of the legislation was to censor films to be shown by film exchanges and theatre owners, the legislation was regulatory in nature and $\mathrm{McNeil}$ was, as a member of the general public, not among the class most directly affected by such regulation. Therefore it seemed that pursuant to the reasoning in Thorson, McNeil would be denied standing. However, such was not the case.

Again, Laskin C.J. wrote the majority opinion. In effect, he qualified the distinction made in Thorson between regulatory and directory legislation in stating that: ${ }^{20}$

It was not a distinction that could be controlling, especially in the light of the reserve of discretion in the Court, and more especially because the word or the term "regulatory" is not a term of art, not one susceptible of an invariable meaning which would in all cases serve to distinguish those in which standing to a taxpayer or citizen would be granted and those in which it would not.

Therefore the mere fact that a certain class or activity was subjected to compulsory regulation on pain of a penalty or other sanction could not always mean that those regulated were the only persons with sufficient stake in the validity of the legislation to have standing to challenge it.

Clearly the theatre owners here were most directly affected by the censorship legislation. However, the public was also affected in that they were precluded from viewing those films censored. In the words of Chief Justice Laskin, "It [the legislation] strikes at the members of the public in one of its central aspects." Nova Scotian public although theatre owners suffered under a more direct effect on their businesses. Furthermore, the interests of the theatre owners were not identical to those of the public.

And once again, Laskin C.J. emphasized that because there was no other way to subject the impugned statute to judicial review, the court

20. Supre n. 4 at 269 .

21. Id. at 271. 
had chosen to exercise its discretion to give the plaintiff standing.

The effect of the McNeil decision on the law of standing has also been summarized in an article by David Mullan which outlines the factors to be considered in the Court's exercise of discretion: ${ }^{22}$

1. The Legislation

a) Is its constitutionality justiciable?

b) Where in the spectrum does it fit between regulatory legislation on the one hand and declaratory or directory legislation on the other?

c) Is it likely to be challenged by anyone within the ordinary standing rules?

d) Who are affected by the legislation and are they affected in a significant way?

e) Is there a substantial, serious question raised by the challenge?

f) Will grave inconvenience result from i) allowing this litigation to proceed, and ii) the possible invalidity of the statute under challenge?

2. The Plaintiff

a) Is the plaintiff directly affected by the legislation, either as a member of the public or in some other capacity?

b) Has the plaintiff explored other avenues of having the constitutional validity of the legislation tested?

Many legal scholars interpreted the $M c N e i l$ decision as eliminating the former distinction between regulatory and declaratory legislation in terms of grounds for standing to challenge and it was "commended as a decision which prevents the establishment of another unsatisfactory legal classification game." ${ }^{23}$ It is submitted that this is misleading because what the judgment states is that any such distinction is not "controlling". And the reason it is not controlling is because of possible ambiguities and uncertainties anticipated in classifying all legislation as either declaratory or regulatory - terms which are themselves uncertain. In fact, this is the very problem which was to arise in the Borowski case.

On careful reading, it is submitted, the distinction between declaratory and regulatory legislation continues to be very significant although it is not a controlling factor in the court's exercise of discretion.

\section{F. THE BOROWSKI DECISION}

The plaintiff in this most recent decision on standing by our Supreme Court has had a long history of opposition to Canadian abortion laws. An heroic and self-sacrificing crusader to some, he is seen by others as a fanatic trying to impose his ethical values on all Canadians. Joseph Borowski is a former M.L.A. and cabinet minister of the province of Manitoba who resigned his seat in the Assembly because he felt that there he was too closely associated with the movement towards making abortions more widely available. He has since addressed the Assembly in opposition to a Budget which appropriated funds to the abortion program. Borowski has served terms in jail because of his beliefs after having refused to pay his taxes on the basis that a percentage of his payments could be used to fund abortions. And he has corresponded with both provincial and federal Ministers and the Official Guardian in an unsuccessful attempt to have one of them move to challenge the legislation.

As a last resort, the plaintiff sought a declaration, as a citizen and taxpayer, that subsections 251 (4), (5), and (6) of the Criminal Code permitting abortions in specified conditions were invalid and inoperative by reason

22. Supra n. 14 at $40-41$.

23. Id. 
of the operation of the Canadian Bill of Rights, specifically subsection 1(a) which reads: ${ }^{24}$

It is hereby recognized and declared that in Canada there have existed and shall continue to exist without discrimination by reason of race, national origin, colour, religion, or sex, the following human rights and fundamental freedoms, namely, the right of the individual to life, liberty, security of the person ...., and the right not to be deprived thereof except by due process of law....

Section 2 of the Canadian Bill of Rights governs its application and provides that: ${ }^{25}$

Every law of Canada shall, unless it is expressly declared by an Act of the Parliament of Canada that it shall operate notwithstanding the Canadian Bill of Rights, be so construed and applied as not to abrogate, abridge or infringe or to authorize the abrogation, abridgment or infringement of any of the rights or freedoms herein recognized and declared. ...

Because the impugned subsections of the Criminal Code were not said to operate notwithstanding the Bill of Rights, the plaintiff alleged that they were therefore inoperative and invalid. In effect the issue sought to be raised by the application was whether the rights protected by the Canadian Bill of Rights were to be extended or construed so as to protect a human fetus.

Mr. Justice Martland, writing for the majority and with six other judges concurring, held that the plaintiff did have standing to bring such an application. The judgment purports to follow the reasoning in Thorson and $M c N e i l$.

The Thorson case, in Mr. Justice Martland's opinion, was decided on the basis that the challenge to the validity of the legislation raised a serious constitutional issue and that there was no other reasonable way to have its validity tested unless an individual citizen could proceed, even though he was not specially affected. He read the $M c N e i l$ case as further extending the grounds for standing in that this decision recognized the possibility of a person having such status even though a class of persons existed which was specially affected or exceptionally prejudiced by the regulatory legislation and of which he was not a member.

Mr. Justice Martland then proceeded to classify the impugned legislation. He found it to be neither regulatory nor declaratory but exculpatory in nature because it provided for an exemption from criminal liability. Therefore he believed it would be difficult to find any class of person directly affected or exceptionally prejudiced by it who would have cause to attack the legislation. He thus discounted the possibility of a doctor, a hospital, a pregnant woman or even a father bringing an action to challenge the abortion laws. Also he considered the issue sought to be raised a matter of considerable importance and decided that there was no other reasonable way to bring the issue into court.

Next, Martland J. compared the interest of Borowski as a plaintiff in this cause of action with that of Thorson and $\mathrm{McNeil}$. Thorson he found to be affected only as a taxpayer and McNeil to be affected only as a member of the public although other people were more directly affected. He concluded that Borowski's position was at least as strong.

Mr. Justice Martland concluded with a new and even broader test for standing which he purported to draw from the Thorson and McNeil cases: ${ }^{26}$

24. Supra n. 2.

25. Id.

26. Supra n.* at 117. 
... to establish status as a plaintiff in a suit seeking a declaration that legislation is invalid, if there is a serious issue as to its invalidity, a person need only show that he is affected by it directly or that he has a genuine interest as a citizen in the validity of the legislation and that there is no other reasonable and effective manner in which the issue may be brought before the court.

With respect, this is not the test established by Thorson and McNeil as outlined above.

A fundamental error in the ratio is, it is submitted, the classification of the legislation challenged. Subsections 251 (4), (5), and (6) are meaningless without reading them together with the rest of the section. The section in its entirety reads:

251 (1) Every one who, with intent to procure the miscarriage of a female person, whether or not she is pregnant, uses any means for the purpose of carrying out his intention is guilty of an indictable offence and is liable to imprisonment for life.

(2) Every female person who, being pregnant, with intent to procure her own miscarriage, uses any means or permits any means to be used for the purpose of carrying out her intention is guilty of an indictable offence and is liable to imprisonment for two years.

(3) .... [definitions]

(4) Subsections (1) and (2) do not apply to

(a) a qualified medical practitioner, other than a member of a therapeutic abortion commit. tee for any hospital, who in good faith uses in an accredited or approved hospital any means for the purpose of carrying out his intention to procure the miscarriage of a female person, or (b) a female person who, being pregnant, permits a qualified medical practitioner to use in an accredited or approved hospital any means described in paragraph (a) for the purpose of carrying out her intention to procure her own miscarriage,

if, before the use of those means, the therapeutic abortion committee for that accredited or approved hospital, by a majority of the members of the committee and at a meeting of the committee at which the case of such female person has been reviewed,

(c) has by certificate in writing stated that in its opinion the continuation of the pregnancy of such female person would or would be likely to endanger her life or health, and

(d) has caused a copy of such certificate to be given to the qualified medical practitioner.

(5) ... [deals with production of the certificate]

(6) .... [definitions]

(7) Nothing in subsection (4) shall be construed as making unnecessary the obtaining of any authorization or consent that is or may be required, otherwise than under this Act, before any means are used for the purpose of carrying out an intention to procure the miscarriage of a female person.

Clearly the section regulates the availability of abortion in Canada. Although subsections (4) and (5) may be exculpatory, this presupposes a regulatory scheme which on its breach may result in a charge and a conviction. Further errors in reasoning are in part based on this fundamental error of classification.

In the instant case, the Criminal Code clearly has a direct effect on a certain class of persons; that is, a class composed of pregnant women in Canada. If a human fetus were to be considered a human being at law, then this is another class of persons directly affected. The legislation also has a more or less direct effect on fathers, doctors, and hospitals. But any effect on the public at large, including Borowski, is at most indirect in spite of any "genuine concern" he might have.

Unlike the plaintiff in $M c N e i l$, the legislation does not prevent Borowski or any other member of the public beyond the class specified from doing anything or exercising any right. Unlike the situation in Thorson, where the legislation was declaratory and affected all citizens alike, here the leggislation regulates a specific class directly, another and larger class less directly but has no real effect on the plaintiff. The situation is analogous to that in $M c N e i l$ and to grant standing to the plaintiff here is similar to granting standing in the McNeil situation to a resident of New Brunswick who opposes the Nova Scotia censorship laws because he has a "genuine interest" in freedom of speech. 
Chief Justice Laskin's dissent, concurred in by Lamer J., is based on the reasoning in Thorson and McNeil. He begins by stating a general proposition with respect to standing: ${ }^{27}$

... as a general rule, it is not open to a person, simply because he is a citizen and taxpayer or is either the one or the other to invoke the jurisdiction of a competent Court to obtain a ruling on the interpretation or application of legislation, or on its validity, when that person either is not directly affected by the legislation or is not threatened by sanctions for an alleged violation of the legisla. tion. Mere distaste has never been a ground to seek the assistance of a court ... the prevailing policy is that a challenger must show some special interest in the operation of the legislation beyond the general interest that is common to all members of the relevant society. This is especially true of the criminal law.

Chief Justice Laskin sees Thorson and McNeil as exceptions to this general rule, both of which are exceptions limited by the controlling judicial discretion associated with them. Again, central to the exercise of discretion are two factors: justiciability of the issue and nature of the legislation.

Both Thorson and McNeil are distinguishable in Chief Justice Laskin's view on the basis of the facts. Whereas Thorson involved declaratory legislation, the instant case consisted of a challenge to provisions of the Criminal Code and, therefore, not all members of the public were affected alike. This was termed "a central consideration". Although the McNeil case was analogous to the instant case in that both involved regulatory legislation, in the former case the plaintiff was also directly affected by the legislation whereas in the latter such was not the case. Furthermore Laskin C.J. was convinced that if the plaintiff here were to be denied standing, it would not mean that there would be no other way to test the alleged inoperability. He thought it quite likely that husbands, if not doctors and hospitals, would challenge the legislation and Laskin C.J. found it more appropriate that such parties with a direct interest in the legislation should be the plaintiffs in any legal action.

In summary then, Laskin C.J. denied the plaintiff standing because he viewed the nature of the legislation as regulatory and without any effect on the plaintiff. He also believed that other reasonable ways of challenging the legislation exist. Therefore he chose to exercise the court's discretion against the plaintiff.

Although the dissenting judgment may appear on cursory reading to be a retreat from the broad grounds of standing as established in Thorson and $M c N e i l$, on careful reading, it is clear that the reasoning in the earlier cases has been followed and consistently applied in the Borowski dissent. Where a plaintiff does not qualify for standing under the general rule of "special interest", then any standing granted is at the court's discretion. Central to the exercise of the court's discretion are two factors: justiciability and the nature of the legislation. If declaratory, it is likely that any member of the public will be allowed standing to challenge its constitutional validity because no one citizen will be any more affected than any other. But where the legislation is regulatory, then those regulated will have standing as well as any member of the public directly affected by the regulatory scheme, pursuant to $M c N e i l$. In neither case is there a suggestion that anyone with a "genuine interest" will have the status to challenge any legislation they choose as stated in the majority opinion of Borowski. The inconsistencies, which seem apparent on first

27. Id at 100 . 
reading of the three opinions by Laskin C.J., stem largely from the sweeping statements made in the introductory and concluding remarks of the decisions and not from the reasoning behind the decisions. On the one hand, he refers to the right of the Canadian citizenry to constitutional behavior by Parliament where the issue in such behavior is justiciable. ${ }^{28}$ This is in sharp contrast to his later statement in Borowski that the courts are dispute-resolving tribunals and do not deal with hypothetical matters "merely to satisfy a person's curiosity or ... obsessiveness with perceived injustice ....".

Implied but never really dealt with is the question of whether the issue sought to be raised is a justiciable one. As was pointed out in a study on locus standi and judicial review by S.M. Thio: ${ }^{30}$

The requirements of standing and justiciability ... overlap, the former concentrating on the position of the applicant in relation to the subject matter of the litigation, and the latter focussing on the fitness for adjudication of the legal issues presented for decision.

And as Ms. Thio has also stated, both the problems of standing and of justiciability of the issue are intertwined with the concept of the role of the judiciary in government. She refers to two possible theories in this respect: ${ }^{31}$

Is the judicial function primarily aimed at preserving legal order by confining the legislative and executive organs of government within their powers in the interest of the public (juridiction de droit objectifl, or is it mainly directed towards the protection of private individuals by preventing illegal encroachments on their individual rights (juridiction de droit subjectif)? The first contention rests on the theory that the courts are the final arbiters of what is legal and illegal. Since the dominant objective is to ensure the observance of the law, this can best be achieved by permitting any person to put the legal machinery in motion. ... Requirements of locus standi are therefore unnecessary in this case since they merely impede the purpose of the judicial function as conceived here. On the other hand, where the prime aim of the judicial process is to protect individual rights, its concern with the regularity of law and administration is limited to the extent that individual rights are infringed, and in the absence of the latter, it does not come into play.

Where a country's constitution allocates power among three branches of government, the legislature, the executive and the judiciary as coordinate organs, Ms. Thio concludes this calls for a system of judicial control or "juridiction de droit objectif". But she is also a ware of the dangers of insensitive judicial intervention because of the anti-democratic nature of the appointments to the judiciary: "To the extent that legislative measures are the expression of the will of the representatives of the people, judicial curtailment constitutes a restraint on majority rule and majority action." ${ }^{32}$

The crucial question then is how the responsibility for establishing social policy is to be shared between Parliament and the Supreme Court of Canada. Although the operation of the Canadian Bill of Rights is obviously a constitutional question for the courts, it is far from clear that the decision to extend its protection to the human fetus is a question for the judicial arena as opposed to the political arena. Arguably the latter is the more appropriate forum because the problem is one which raises ethical, religious, medical, social and political questions as well as legal issues. Parliament as a representative assembly of the Canadian people would

28. Supra n. 3 at 163 .

29. Supra n. * at 100.

30. S.M. Thio, Locus Standi and Judicial Review (1971) 54.

31. Id. at 2-3.

32. Id. at 3. 
appear to be in a better position to make such a policy decision than nine persons chosen by the executive branch of government.

This is not intended to reject the values behind legislation with respect to human rights or the duty of the courts to interpret such legislation. However, were the court in future to reach a decision extending the protection in such legislation to a class of "beings" which clearly was not in the minds of Members of Parliament who passed the Bill, this would be an intolerable interference with the democratic process, especially in view of other legislation validly enacted which rejects such a position. Perhaps the simplest solution would be to include a provision in the Criminal Code that the abortion laws shall operate notwithstanding the Bill of Rights or alternatively, an amendment to the human rights legislation to the effect that a human fetus is not intended to be included in the protected class.

\section{G. EFFECT OF THE BOROWSKI DECISION}

Mr. Justice Martland's majority opinion in Borowski sets a new test in Canada for standing to challenge the constitutional validity of legislation: if there is a serious issue, any member of the public need only show that he is affected directly or has a genuine interest as a citizen and that there is no other reasonable and effective manner in which the issue may be brought to court. It is difficult to think of how the grounds for standing could be made much broader without eliminating the concept of standing from the judicial system.

This at once gives rise to the "floodgates" argument which has been put forward in the past as an argument against any progressive changes in the process or substance of the law. The argument has therefore spurred legal writers to such sarcastic comments as: "The idle and whimsical plaintiff, a dilettante who litigates for a lark is a specter which haunts the legal literature, not the courtroom."33 First of all, such writers point to the time and expense involved in frivolous litigation. Some go so far as to say that if a citizen finds a legal issue as to the validity of certain legislation to be of such personal importance that he is willing to finance the legal challenge himself, he should be allowed to do so. ${ }^{34}$

However, the situation in Canada may well be drastically altered by The Canada Act and the Charter of Rights. Whereas the Canadian Bill of Rights had been so qualified by judicial interpretation that its real value in protecting human rights was considered to be minimal and therefore it was seldom raised, the new Charter will likely provide a host of legal challenges in the near future. Given the new and ever broader test of standing to challenge the constitutional validity of legislation, Canadian courts should anticipate that the "floodgates" threat may soon become a reality. 